\title{
Anthony Applemore Mornington Bryer 31 October 1937 to 22 October 2016
}

\author{
Stephen Hill \\ Acting Deputy Vice-Chancellor, University of Gibraltar \\ stephen.hill@unigib.edu.gi
}

$I^{\prime}$ is with great sadness that we record the death of Anthony Bryer at the age of 78 on 22 October 2016. Anthony Applemore Mornington Bryer, to give him his full name, though everyone knew him simply as Bryer, was a long-term trustee of the British Institute at Ankara (BIAA), served on several of its committees and, most significantly, was Editor of Anatolian Studies from 2001 to 2008 and President from 2003 to 2008. In these roles Bryer made a lasting contribution to the well-being of the Institute. He did this with supreme professionalism and humanity, as Gina Coulthard, who worked so closely with him, has attested: (working with Bryer) 'was a total pleasure, joy and honour. He was interested in absolutely everything and everyone, and that meant that he happily gave his time and energies to all the articles submitted to Anatolian Studies, whatever their subject, and would offer wise words and encouragement to each and every one our authors - the younger scholars in particular. He may have given the impression of being an eccentric academic, but he was actually amazingly efficient; he always replied to emails immediately and I never once had the feeling I was being a nuisance, however demanding I was of him. He also approached everything he did with an utterly hilarious sense of humour - and had an almost unbelievable anecdote for just about every situation - but at the same time he constantly worked seriously and conscientiously, and he could see something worthwhile in every article submitted to us.'

Although his formal service to the BIAA came relatively late in his career, Bryer's connection with Anatolia and, in particular, with Trabzon and the Black Sea can be traced back to undergraduate and postgraduate theses at Oxford, and even, perhaps to a childhood birthday present of a coin of the Empire of Trebizond. Whilst he can reasonably be remembered as the person who did most to make Byzantine studies a respected subject in British academia, he must also be seen, with scholars like Martin Harrison and Michael Gough, the former director of the BIAA, as part of a longestablished Institute tradition of Byzantine research, one of the giants on whose shoulders subsequent generations of scholars interested in Byzantine Anatolia stand.
Bryer's fieldwork in the Pontos, conducted in fruitful collaboration with David Winfield, resulted in the publication, in 1989 in two volumes, of The Byzantine Monuments and Topography of the Pontos, which, along with a host of articles on the Empire of Trebizond (many captured and represented in three volumes published by Variorum), stand as the formidable and illuminating legacy of Bryer's meticulous scholarship, and his enormous capacity for intricate and yet entertaining story-telling. The Pontos volumes form an academic tour-de-force stuffed with authoritative and comprehensive reference to a bewildering range of Byzantine historical sources, and yet, thanks to Bryer's narrative skills and his fascination with outré detail, they are a captivating read, a sort of travel book par excellence. The character of the book perfectly reflects the character of the man.

Bryer was always deeply committed to spreading the good news about Byzantium as widely as possible, and, accordingly, published remarkable pieces in accessible journals such as History Today and Cornucopia where his more 'popular' pieces, still meticulously researched and evidenced, gave him scope for the admixture of his wit, raconteurship and utterly infectious enthusiasm about all things Byzantine, however obscure or apparently unlikely. Bryer's early publications, though in an untraditional area of historical research, were firmly rooted in the mainstream of historical process, but as he grew older, he allowed himself more freedom to ramble away from the historical strait and narrow towards more personal enthusiasms, especially agricultural implements and, above all, the history of food, of which he was both a passionate researcher and consumer.

Though he was hugely well-travelled in northern Anatolia, Bryer's engagement with practical archaeology in Anatolia also came late in his career, when he partook in fieldwork wielding a billhook at Buzluca with Jim Crow in 1994 and working on the excavation at Çiftlik with me in 1997. In these activities, Bryer demonstrated simultaneously the extraordinary depth of his command of the Byzantine sources, his characteristic clumsiness and lack 


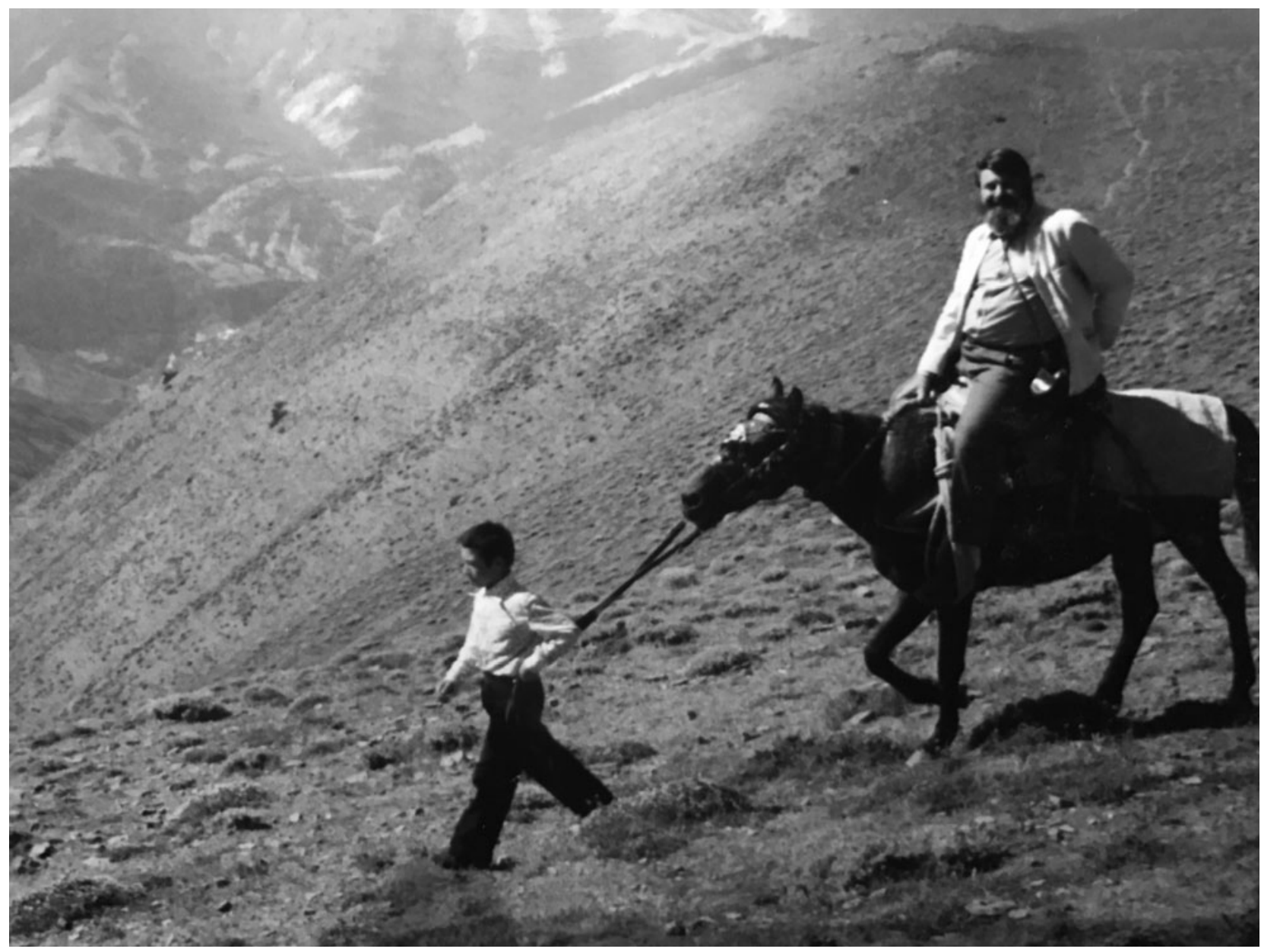

Bryer riding in the yayla (photograph by Katie Bryer).

of the practicality which is necessary for archaeologists in the field, his fascination with agricultural implements and culinary traditions, and, above all, his extraordinary generosity of spirit and enthusiasm for sharing his knowledge with younger scholars. When Bryer was with you there were always adventures and hilarity, and in an attempt to capture some of the sense of Bryer as the huge and multifaceted, generous, character that he was I offer an account of an adventure which Gina Coulthard and I enjoyed when Bryer was with us at Çiftlik.

Bryer had immense presence, indeed a sort of aura of grandness which drew fascinated crowds when he came to Sinop to join our excavation at Çiftlik. Princess Diana died on 31 August 1997. That was a Sunday, our day off. Bryer heard the news in Sinop in a cafe by the harbour whilst writing a speech in his capacity as public orator for the University of Birmingham. We found him there, smoking his pipe and enjoying the local blackberry ice cream, attended by a group of Sinop worthies who were commiserating with him over his terrible loss in long-winded sonorous Ottoman condolences. Bryer was in his element, especially as the sonorous condolences were to be repeated for days thereafter.
Sinop was, for Bryer, an inferior relative of Trabzon, too far west for the kemence, the Pontic lyre, but it still had the Black Sea, hamsi and tarhana, so it was OK. He was immediately accorded the title of Hoca by the Sinopitans. When we took him out to Çiftlik, the villagers similarly immediately acclaimed him as Bryer Hoca, whereas it had taken me years to be promoted from Amca to Hoca. Once there were two hocas at the excavation, it was necessary to find an epithet to distinguish one from the other, and Bryer quickly became known as the Hoca-with-red-socks.

It was Bryer, of course, who identified Çiftlik as Kyptasia, and the church we were excavating as the martyrium of St Phokas of Sinop, the patron saint of gardeners. Phokas was martyred at the hands of Roman soldiers who were marching from Amaseia to Sinope. When Gina and I announced that we were planning a weekend excursion to visit Amasya, Bryer insisted on coming too saying 'But we must also go to Tokat'. When we asked him, 'Why Tokat?', the unexpected response was 'tablecloths Tokat tablecloths; we must have tablecloths from Tokat!'

One of Bryer's lifelong interests was food, and at the time when he came to Sinop he was the Honorary Secretary of the Buckland Dining Club, so named after 


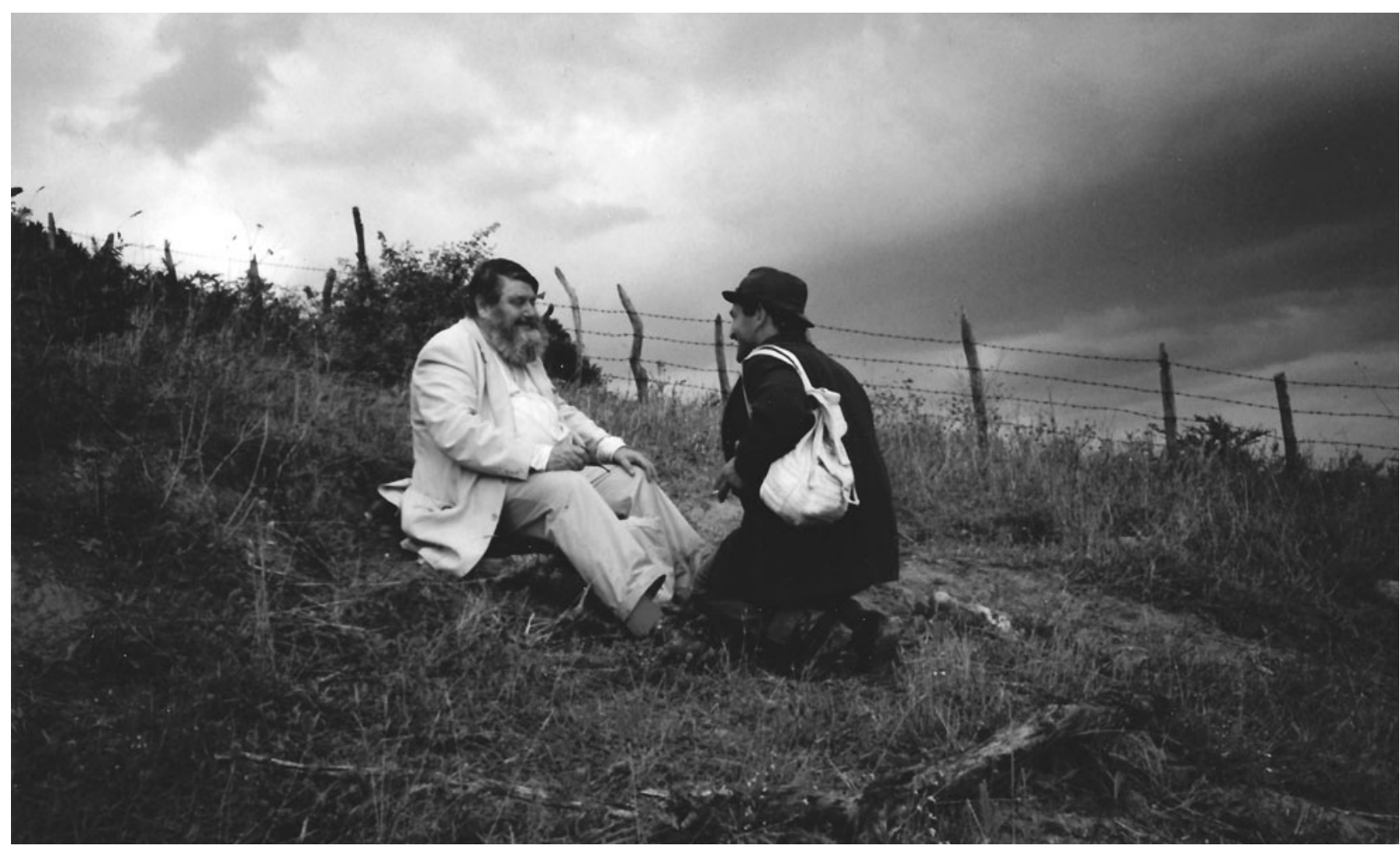

Bryer with Talep Bey, Deputy Muhtar of Çiftlik in 1997 (photograph by Gina Coulthard).

William Buckland, the Georgian eccentric whose mission it was to eat a portion of every animal in the world that was eatable (if not actually edible). The club met twice a year in Birmingham, often in the Staff Club of the University, and we were planning a club meal based on the traditional Black Sea food still enjoyed in villages like Çiftlik. Bryer was never happier than when he was sourcing materials for the latest Buckland Club extravaganza, and, on this occasion, he was determined to acquire for the next Buckland Club dinner a supply of the naively blockprinted tablecloths which are a speciality product of Tokat.

The trip to Amasya and Tokat was set for Saturday 6 September, but there was a problem. 'How will I be able to watch Diana's funeral?' This surprisingly Royalist anxiety could only be countered by 'Well, you wouldn't be able to watch it in a field beside the Black Sea anyway.'

The trip to Tokat became something of a royal progress, with the Bryer of The Byzantine Monuments and Topography of the Pontos providing running commentary and demanding occasional detours to important places like Merzifon, which he declared to be 'disappointing'. But between Amasya and Tokat, we were bidden to stop in a roadside çayhane. The customers were contentedly eating, drinking tea and watching football on the television. Bryer made his grand entrance, and disappeared to talk to the proprietor. As if by magic, a space was cleared by the television, the channel was changed and Bryer was able to watch Princess Diana's funeral in the middle of Anatolia. Sadly, the fabric factory was closed and our search for tablecloths at Tokat was frustrated.

Back at Çiftlik, Bryer was once again greeted with formal condolences (see photo above) and spent much of that day in the çağdır (tea hut) very happily discussing Pontic recipes and the best agricultural tools and techniques for back-filling archaeological trenches.

Bryer was a phenomenon, a great scholar and colleague, an entertaining story-teller, always ready with a fascinating digression, occasionally mischievous, but constantly generous and humane. His contribution to the British Institute at Ankara is part of his legacy to Byzantine studies and evidence of his great humanity. He is sorely missed. 